Article

\title{
Training of Electric Bike Assembly with Lithium-Ion Batteries at SMK Muhammadiyah 6 Karanganyar
}

\author{
Tika Paramitha ${ }^{1,}$, Endah R Dyartanti ${ }^{1}$, Hendri Widiyandari ${ }^{2}$, Arif Jumari ${ }^{1}$, Adrian Nur ${ }^{1}$, \\ Inayati $^{1}$, Anatta W Budiman ${ }^{1}$, and Agus Purwanto ${ }^{1}$ \\ 1 Program Studi Teknik Kimia, Fakultas Teknik, Universitas Sebelas Maret \\ 2 Program Studi Fisika Fakultas MIPA, Universitas Sebelas Maret \\ E-mail:*tikaparamitha@staff.uns.ac.id (Corresponding author)
}

\begin{abstract}
Abstrak. Dengan perkembangan industri baterai dan kendaraan listrik yang semakin meningkat, pemahaman siswa dan guru mengenai baterai ion lithium dan keterampilan dalam merakit sepeda listrik sangat penting dalam persaingan mendapatkan pekerjaan di bidang tersebut. Kegiatan edukasi mengenai baterai dan pelatihan perakitan sepeda listrik dilakukan di SMK Muhammadiyah 6 Karanganyar, karena belum tersedia fasilitas yang mendukung proses belajar dan mengajar mengenai kendaraan listrik dan baterai. Metode yang dilakukan dalam pelatihan ini adalah metode ceramah, diskusi dan praktik. Adapun materi yang disampaikan mengenai teknologi pembuatan baterai ion lithium dan komponen-komponen sepeda listrik. Sedangkan kegiatan praktik meliputi tahapan-tahapan konversi sepeda konvensional menjadi sepeda listrik dengan energi dari baterai ion lithium. Hasil kegiatan ini adalah peserta dapat memahami baterai dan dapat mengaplikasikan baterai untuk kendaraan listrik, khususnya sepeda listrik.
\end{abstract}

Kata Kunci: Baterai Ion Lithium, Perakitan, Sepeda Listrik

\begin{abstract}
With the increasing development of the battery and electric vehicle industry, student's and teacher's understanding of lithium-ion batteries and skills in assembling electric bike are very important in competing for jobs in these fields. Educational activities regarding batteries and training on assembling electric bike are carried out occurred at SMK Muhammadiyah 6 Karanganyar, because there were no facilities that support the learning and teaching process about electric vehicles and batteries. The method used in this training is lecture, discussion and practice method. The material presented was about the technology of making lithium-ion batteries and electric bike components. At the same time, practical activities include the stages of converting conventional bike into electric bike with energy from lithium-ion batteries. This activity shows that participants can understand batteries and can apply batteries to electric vehicles, especially electric bike.
\end{abstract}

Keywords: Lithium-Ion Batteries, Assembly, Electric Bike

EQUILIBRIUM Volume 5 No.1 July 2021

Online at http:// equilibrium.ft.uns.ac.id 


\section{Introduction}

At this time, fossil energy is widely used in various sectors of people's lives. The use of fossil energy reaches 95\% of the energy needs in Indonesia [1]. The use of fossil energy can increase the concentration of exhaust gases $\left(\mathrm{CO}_{2}, \mathrm{CH}_{4}, \mathrm{~N}_{2} \mathrm{O}, \mathrm{HFCs}, \mathrm{PFCs}, \mathrm{SF}_{6}\right)$ which causes global warming [2]. In addition, the increasing use of fossil energy is not matched by the existing fossil energy reserves in Indonesia. These conditions can threaten energy security. Therefore, the use of new and renewable energy (NRE) such as solar energy, wind and water power, oil from plants, wood from sustainable sources, other forms of biomass (plant material), and biogas (gas produced from the fermentation of manure and crop residues) has become the attention [3].

The transportation sector is a significant contributor to fossil fuel consumption and greenhouse gas emissions [4]. Energy needs, especially in the transportation sector, are projected to increase by 3.5 times in 2050 compared to the base year of 2017 [5]. One of the government policies in the transportation sector is Peraturan Presiden no. 55/2019, to develop battery-based electric vehicles that include cars, buses and motorcycles. Electric vehicles can reduce fuel consumption and carbon emissions [6] because electric vehicles can use all types of energy converted into electrical energy, such as electrical energy from new and renewable energy. In addition, electric vehicles have low engine noise levels, low emissions, and high energy efficiency [7]. Generally, there are two main types of electric vehicles: Battery Electric Vehicles (BEV) and Plug-in Hybrid Electric Vehicles (PHEV). BEV rely on the energy stored in the battery storage. Meanwhile, PHEV rely on the energy stored in battery storage and fossil fuels [8].

One of the electric vehicles is the electric bike. An electric bike is a modification of a conventional bike. A conventional bike is driven using a pedal, but an electric bike has an additional battery and an electric motor [9]. Currently, the number of electric bike users has increased quite high. However, the available workshops are not matched by the increasing number of electric bike users. Lack of knowledge and competence regarding the electric bike system is one of the causes for the lack of electric bike workshops [10].

In line with government policies regarding the acceleration of the development of electric vehicles and the needs of electric bike experts, Vocational High School (SMK) must be ready to face these technological developments [11]. Therefore, Vocational High School with the Department of Light Vehicle Engineering and Electronics Engineering should prepare graduates with electric vehicles and energy storage competence. The expertise of vocational students in electric vehicles and energy storage will be a provision for a job competition. However, success in developing electric vehicles has not occurred at SMK Muhammadiyah 6 Karanganyar because no complete facilities support the learning and teaching. In addition, the pandemic condition also affects the learning process in the school. Vocational High School students cannot do practical activities at school because the learning is done online. Lack of practical activities can reduce student competence.

Based on the problem above, community service decides to share knowledge about lithium-ion batteries. Recently, lithium-ion batteries are the most popular batteries in electric vehicles. The characteristic of batteries for electric vehicles should have a high energy density, lightweight, resistance to high temperatures, high efficiency, high discharge rate, and safety [12]. Furthermore, community service also gives training on assembling the electric bike for improving students and teachers competence in electric vehicles.

\section{Method}

The method of implementing community service is shown in Figure 1, which is divided into three stages as follows. 


\section{Preparation Stage}

coordination between the community service team and partners

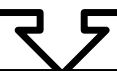

Implementation Stage

giving education about lithium-ion batteries and training on assembling the electric bike

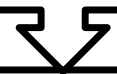

\section{Evaluation Stage}

giving an online questionnaire to assess the community service activities and ask suggestions

Figure 1. The method of implementing community service activities

The stages of implementing community service activities in Figure 1 can be described as follows:

1. Preparation Stage

At the preparation stage, coordination between the community service team and partners (SMK Muhammadiyah 6 Karanganyar) is carried out to analyze problems that occur in partners. The community service team discusses the issues to find solutions. The solutions are giving education about lithium-ion batteries and training in assembling the electric bike. Furthermore, the solutions are re-coordinated with partners, such as the implementation schedule, materials, and other matters.

\section{Implementation Stage}

At the implementation stage, community service activities are carried out using lecture, discussion, and direct practice methods, which consist of:

a Learning materials on lithium-ion batteries manufacturing technology

This activity is carried out by the lecture method followed by the question and answer method (discussion). Material is delivered via PowerPoint with the Zoom video conference application (online).

b Learning materials on the electric bike

This activity is carried out with the same method as the activity on point a. But the material is delivered by directly showing the components of the electric bike (offline).

c Practice in assembling the electric bike

The practice begins with a demonstration method to explain how to assemble the electric bike. Then, students practice the steps of assembling the electric bike according to the explanation in the previous demonstration.

\section{Evaluation Stage}

At the evaluation stage, the community service team gives an online questionnaire using a google form. In the questionnaire, the results of the participant's assessment of activities and suggestions will be obtained. These suggestions are used to improve future community service activities. The questionnaire uses a Likert scale ranging from $1-4$, as shown in Table 1.

Table 1. The questionnaire description

\begin{tabular}{|c|c|c|}
\hline \multirow{2}{*}{$\begin{array}{c}\text { No } \\
1\end{array}$} & Question Description & Scale \\
\hline & Kegiatan pengabdian masyarakat memberikan manfaat bagi peserta & 1: Sangat tidak setuju \\
\hline 2 & $\begin{array}{l}\text { Materi pengabdian yang disampaikan dapat dipahami } \\
\text { (The material delivered can be understood) }\end{array}$ & $\begin{array}{l}\text { 3: Agak setuju } \\
\text { 4: Sangat setuju }\end{array}$ \\
\hline \multirow[t]{2}{*}{3} & Metode dalam penyampaian materi tepat (metode ceramah, diskusi, dan & \\
\hline & $\begin{array}{l}\text { praktik) } \\
\text { (The method in delivering the material is suitable (lecture, } \\
\text { discussion, and practice method)) }\end{array}$ & $\begin{array}{l}\text { 1: Strongly disagree } \\
\text { 2: Somewhat disagree } \\
\text { 3: Somewhat agree }\end{array}$ \\
\hline 4 & $\begin{array}{l}\text { Media pembelajaran mendukung kegiatan pengabdian masyarakat (praktik } \\
\text { secara langsung perakitan sepeda listrik) } \\
\text { (Learning media supports community service activities (the direct } \\
\text { practice of assembling electric bike)) }\end{array}$ & 4: Strongly agree \\
\hline 5 & $\begin{array}{l}\text { Keinginan melanjutkan materi lebih mendalam } \\
\text { (Desire to continue the material more deeply) }\end{array}$ & \\
\hline
\end{tabular}

Training of Electric Bike Assembly with Lithium-Ion Batteries at SMK Muhammadiyah 6 Karanganyar 17 Tika Paramitha, Endah R Dyartanti, Hendri Widiyandari, Arif Jumari, Adrian Nur, Inayati, Anatta W Budiman, and Agus 


\section{Result and Discussion}

This activity was attended by seven students and seven teachers at SMK Muhammadiyah 6 Karanganyar. Implementing community service activities on assembling electric bike using lithium-ion batteries is carried out in several stages. These activities are divided into three main activities, namely:

\subsection{Learning materials on lithium-ion batteries manufacturing technology}

The material was delivered online to anticipate crowds of people in the classroom. The video recording of this activity is shared at the link https://youtu.be/qmanWK5aNZk. The activity of learning materials on lithium-ion batteries manufacturing technology was shown in Figure 2. Figure 2.a shows the zoom view of the speaker explaining the lithium-ion batteries manufacturing process, and Figure 2.b shows the condition of students and teachers in the classrooms of SMK Muhammadiyah 6 Karanganyar.

In this activity, the material presented includes the type of battery cathode, the shape of the lithiumion batteries, and the steps of making lithium-ion batteries. The types of battery cathodes that are widely used include Lithium Ferro Phosphate (LFP), Lithium Nickel Manganese Cobalt Oxide (LNMC), Lithium Nickel Cobalt Aluminum Oxide (LNCA), and Lithium Cobalt Oxide (LCO). The shapes of lithium-ion batteries are cylindrical cells, prismatic cells, coin cells, and pouch cells. The material of the stages of making lithium-ion batteries was also presented to give an overview to students and teachers regarding the process and tools of the mini-plant scale at Centre of Excellence for Electrical Energy Storage Technology, Universitas Sebelas Maret, Surakarta. The lithium-ion batteries manufacturing process includes manufacturing active electrode material, mixing electrode slurry, making electrode sheets, rolling electrode and separators (roll), welding roll with casings, grooving and joining roll with casing caps, filling electrolyte in glove boxes, closing the casing caps, and testing battery.

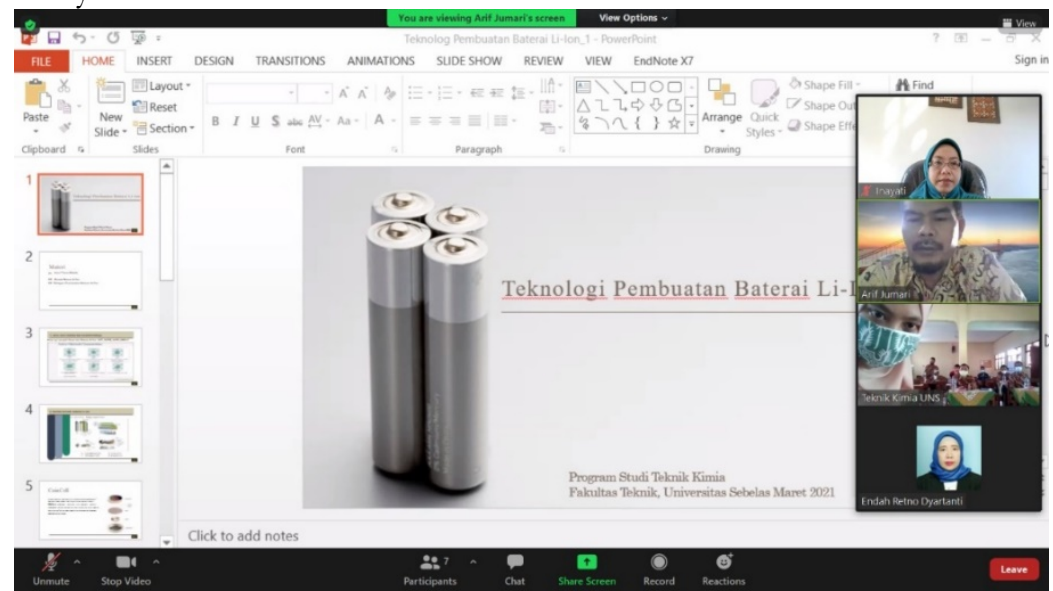

(a)

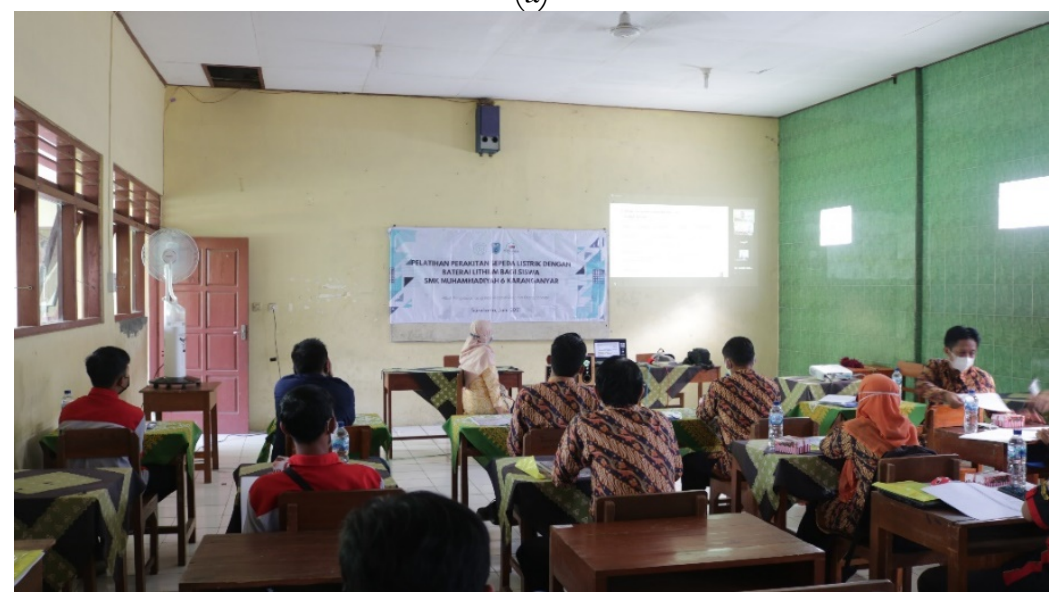

(b)

Figure 2.a The zoom view of the speaker, 2.b The condition of participants in the classroom on lithiumion batteries manufacturing technology learning materials 


\subsection{Learning materials on the electric bike}

The material about the electric bike was delivered offline to increase participant's understanding. The speaker explained the components that need to be replaced to convert a conventional bike into an electric bike, as shown in Figure 3. This activity also aims to provide knowledge about the functions of electric bike components.

The main components in the conversion of the electric bike are motors, batteries, controllers. In addition, several accessories can be added to the electric bike, namely pedal assist, gas handle, monitor display, and rim handle. The components of the electric bike in detail are shown in Figure 4.

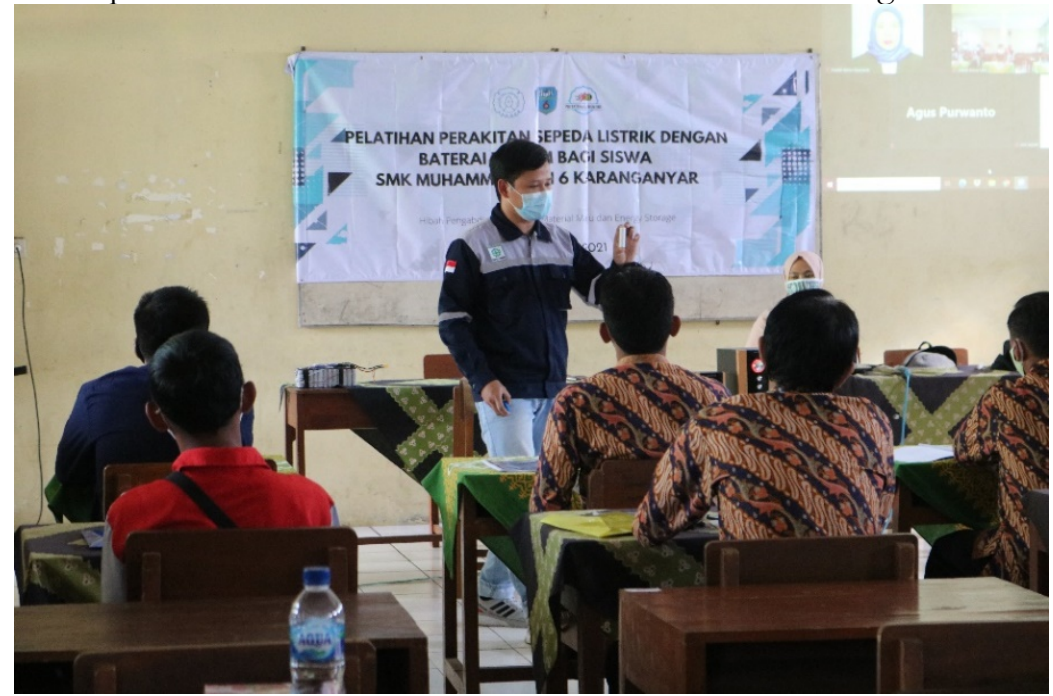

Figure 3. The condition of participants in the classroom in the learning materials on the electric bike

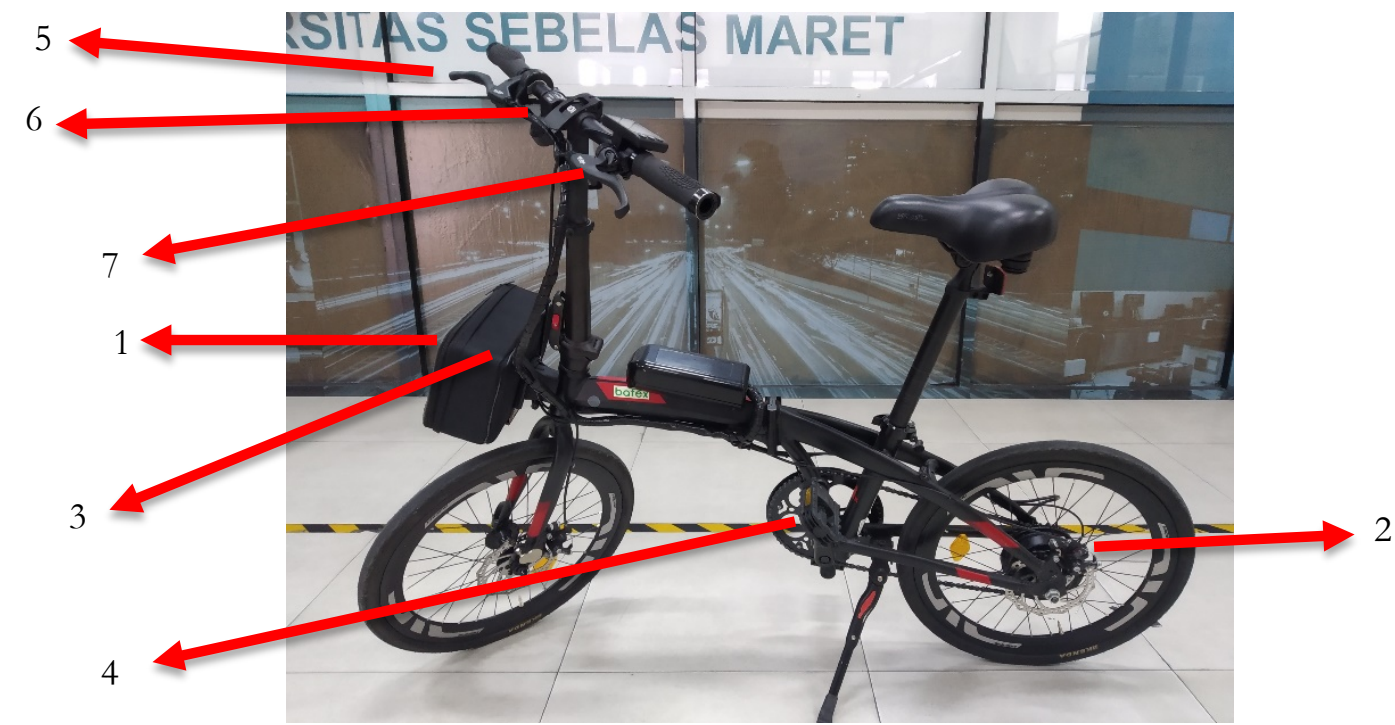

Detail information:

1. Battery

2. Electric motor

3. Controller

4. Pedal Assist Sensor

5. Gas Handle

6. Display Monitor

7. Handle Rim

Figure 4. The electric bike components 


\subsection{Practice in assembling the electric bike}

In this activity, the community service team demonstrated the assembly of the electric bike. Next, students assemble the electric bike according to the instructions, which is shown in Figure 5. This activity is carried out to reduce the gap between theoretical and practical understanding to increase student's knowledge of electric vehicles. The video recording of this activity is shared at the link https://youtu.be/-li0EPQNzBY. The steps in assembling the electric bike are:
a. Installing the rear wheel and electric motor
b. Setting the phase cable and hall sensor cable
c. Installing the case and cable controller
d. Installing the monitor display
e. Installing the gas throttle
f. Installing the handgrip
g. Positioning components on the bike handlebar
h. Installing the pedal assist sensor
i. Installing the controller cable
j. Installing and adjusting rims
k. Installing lithium-ion batteries
1. Testing the function of electric bike components

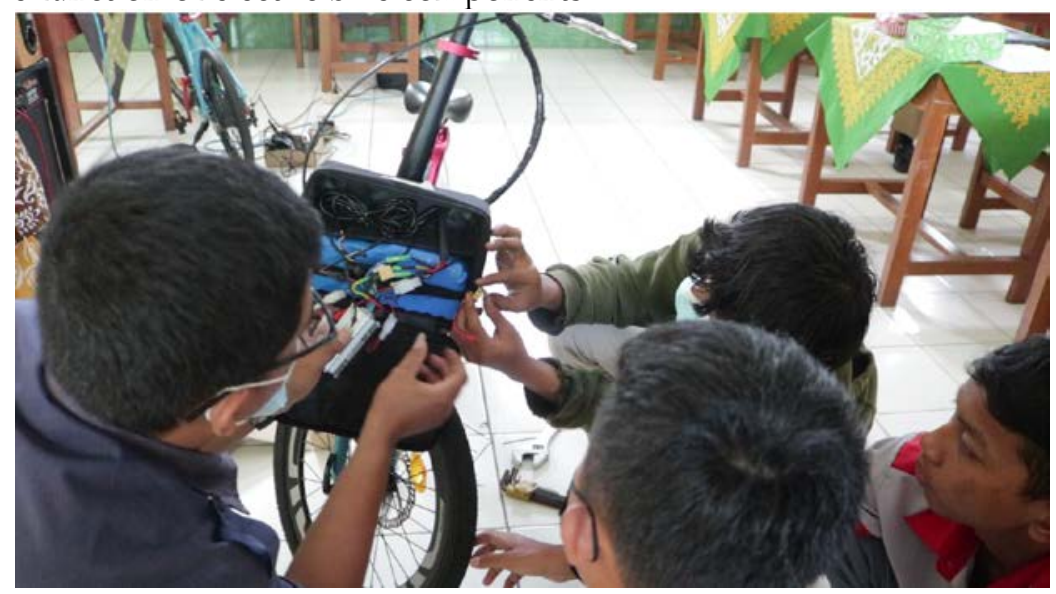

Figure 5. Electric bike assembly by students

\subsection{Activity Evaluation}

At the evaluation stage, the community service team distributed an online questionnaire using a google form to determine the level of satisfaction of students and teachers at SMK Muhammadiyah 6 Karanganyar with activities. The results of the questionnaire are shown in Table 2. Based on Table 2, the level of participant satisfaction regarding community service activities is quite good, with an average score of $3.4(85 \%)$ on a scale of $4.0(100 \%)$. Question number 1 (the usefulness of activities), number 3 (methods of delivering material), and number 4 (learning media) have values above average. In contrast, question number 2 (the ease of understanding the material) and number 5 (the desire to continue the material deeper) is less than average. These values are obtained because the material presented is new for the participants, so participants need time to understand and have the willingness to learn more about the material presented. 
Table 2. Level of satisfaction of students and teachers at SMK Muhammadiyah 6 Karanganyar

\begin{tabular}{clcc}
\hline No & \multicolumn{1}{c}{ Question Description } & Mean & Percentage (\%) \\
\hline 1 & $\begin{array}{l}\text { Community service activities provide benefits for } \\
\text { participants }\end{array}$ & 3.64 & 90.91 \\
2 & $\begin{array}{l}\text { The material delivered can be understood } \\
\text { The method in delivering the material is suitable } \\
\text { (lecture, discussion, and practice method) }\end{array}$ & 3.27 & 81.82 \\
4 & $\begin{array}{l}\text { Learning media supports community service } \\
\text { activities (the direct practice of assembling electric }\end{array}$ & 3.55 & 88.36 \\
$\quad \begin{array}{l}\text { bike) } \\
5\end{array}$ & Desire to continue the material more deeply & 3.09 & 77.27 \\
\hline \multicolumn{1}{c}{ Total } & $\mathbf{3 . 4 0}$ & $\mathbf{8 5 . 0 0}$ \\
\hline
\end{tabular}

The participants give several suggestions for the following community service activities, namely training on assembling other electric vehicles, such as motorcycles and cars, and other household appliances. In addition, training can also be carried out at Centre of Excellence for Electrical Energy Storage Technology, Universitas Sebelas Maret, Surakarta.

\section{Conclusion}

The training on assembling an electric bike with lithium-ion batteries is carried out through 3 series of activities: delivering material on lithium-ion batteries, delivering material on the electric bike, and assembling the electric bike. The direct practice of assembling the electric bike will improve the understanding of participants. These community service activities are successfully conducted at SMK Muhammadiyah 6 Karanganyar, as shown in participant's level of satisfaction with an average score of $3.4(85 \%)$ on a scale of $4.0(100 \%)$.

\section{Acknowledgement}

The author would like to thank Sebelas Maret University which has funded the community service activities entitled "Pelatihan Perakitan Sepeda Listrik Dengan Baterai Lithium Bagi Siswa SMK Muhammadiyah 6 Karanganyar" (PKM HGR-UNS) with NON APBN UNS at 2021 and a contract letter Number: 261/UN27. 22/HK.07.00/2021. In addition, the authors also thank SMK Muhammadiyah 6 Karanganyar for their facilities and participation in this activity.

\section{Reference}

[1] D. R. Putra, D. Yoesgiantoro, and S. Thamrin, "Kebijakan Ketahanan Energi Berbasis Energi Listrik Pada Bidang Transportasi Guna Mendukung Pertahanan Negara Di Indonesia: Sebuah Kerangka Konseptual," J. Ilmu Pengetah. Sos., vol. 7, no. 4, pp. 658-672, 2020.

[2] D. Windyswara, "Alasan pemerintah Indonesia meratifikasi paris climate agreement tahun 2016," eJournal Ilmu Hub. Int., vol. 7, no. 1, pp. 69-90, 2019, [Online]. Available: http://unfccc.int/kyoto_protocol/items/2830.php.

[3] A. P. S.M Ali, Nutan Dash, "Role of renewable energy on agriculture," Int. J. Eng. Sci. Emerg. Technol., vol. 4, no. 1, pp. 51-57, 2012.

[4] V. Tulus Pangapoi Sidabutar, "Kajian pengembangan kendaraan listrik di Indonesia: prospek dan hambatannya," J. Paradig. Ekon., vol. 15, no. 1, pp. 21-38, 2020, doi: 10.22437/paradigma.v15i1.9217.

[5] BPPT, Indonesia Energy Outlook. 2019: The Impact of Increased Utilization of New and Renewable Energy on the National Economy. 2019.

[6] D. M. Yulanto et al., "Studi analisis perkembangan teknologi kendaraan listrik hibrida," vol. 02, no. 1, pp. 31-44, 2021.

[7] D. Prianjani and W. Sutopo, "Studi Komparasi Penelitian Standar Kendaraan Listrik Dunia dengan Standar Kendaraan Listrik Indonesia," Pros. SNST ke-9, p. 13, 2018.

Training of Electric Bike Assembly with Lithium-Ion Batteries at SMK Muhammadiyah 6 Karanganyar 21 Tika Paramitha, Endah R Dyartanti, Hendri Widiyandari, Arif Jumari, Adrian Nur, Inayati, Anatta W Budiman, and Agus 
[8] M. Aziz, Y. Marcellino, I. A. Rizki, S. A. Ikhwanuddin, and J. W. Simatupang, "Studi Analisis Perkembangan Teknologi Dan Dukungan Pemerintah Indonesia Terkait Mobil Listrik," TESLA J. Tek. Elektro, vol. 22, no. 1, p. 45, 2020, doi: 10.24912/tesla.v22i1.7898.

[9] D. T. Arsari, "Legalitas Penggunaan Sepeda Listrik Sebagai Alat Transportasi Menurut Perspektif Hukum Pengangkutan Di Indonesia," Jurist-Diction, vol. 3, no. 3, p. 903, 2020, doi: 10.20473/jd.v3i3.18629.

[10] A. Kurniawan, F. A. Budiman, D. P. Laksono, and A. Arifah, "Pelatihan Perakitan Sepeda Listrik pada Mahasiswa," pp. 51-54, 2019.

[11] A. S. Ardiyanta, "Kesiapan Smk Menghadapi Perkembangan Teknologi Kendaraan Listrik," JIPI Jurnal Ilm. Penelit. dan Pembelajaran Inform., vol. 2, no. 1, pp. 37-42, 2017, doi: 10.29100/jipi.v2i1.231.

[12] N. M. A. Wijaya, K. I. N. S., P. C. G. I., and Y. Divayana, "Perkembangan Baterai Dan Charger Untuk Mendukung," vol. 8, no. February, pp. 15-26, 2021, doi: 10.24843/SPEKTRUM.2021.v08.i01.p3. 